\title{
IMPACT OF GLOBALIZATION ON THE PERFORMANCE OF THE COMPANY: THE CASE OF COMPANIES FROM BOSNIA AND HERZEGOVINA
}

\author{
Hasan Mahmutović \\ Sead Talović \\ Safet Kurtović
}

Original scientific paper

DOI: $10.21554 /$ hrr.041705

Faculty of Economics, University of Zenica

Faculty of Management and Business Economics, University of Travnik

Ministry of Foreign Trade and Economic Relations BiH

Received: 13.11 .2016

Accepted: 08.02.2017

\begin{abstract}
The discourse of globalization and its effects have been the most current topic in the field of economics in recent times. However, empirical research on the impact of globalization on companies, especially in transition countries, is very scarce. This paper focuses on the study of the impact of globalization on the performance of companies in Bosnia and Herzegovina by analyzing their interrelationships. The findings, in the case of companies in Bosnia and Herzegovina, have confirmed earlier findings about the double impact of globalization by showing, on the one hand, its positive effects and, on the other hand, the negative effects on the performance of the companies. Additionally, the research results have shown that negative effects are felt more strongly in the case of small and medium-sized companies than in the case of large companies.
\end{abstract}

Keywords: globalization, firm performance, small and medium-sized companies, empirical research JEL Classification: $F$ 60, L 25, C 40

\section{INTRODUCTION}

Although globalization is a multidimensional phenomenon, a particularly notable occurrence in most of the papers is the domination of economic aspects related to the essence of this concept, which are interpreted as a generator of the entire process. According to Oman (1999), economists view globalization through the prism of removing barriers to international economic activities. This viewpoint indicates that globalization implies widening of the scope of mutual relations between national economies i.e. increase in movement of goods, workforce, capital and foreign direct investment (Acocella, 2005; Jempa \& Rhoen, 1996; Easterly, 2004) and achievement of integration of international commodity markets (O'Rourke \& Williamson, 2000). In this context, Stiglitz (2002, p. 29) defines globalization as ,,increasing interconnectedness of the world's countries and nations, which has brought about a huge reduction in transport and communication costs and removal of artificial barriers to the flow of goods, services, capital, knowledge and (to a lesser extent) people across borders". The result of these globalization processes is an exorable integration of markets, national states and technologies, as well as the spread of the free market capitalism over practically all the countries in the world (Friedman, 2000). 
Based on the aforementioned viewpoints of certain authors, it can be concluded that the key economical aspects of globalization, as a common denominator, pertain to removal of barriers to the free flow of people, goods and capital across national borders, closer interconnectedness of players on the world economic stage and achievement of integration processes. Globalization as such (determined by the said aspects) undoubtedly impacts national economies and companies worldwide. These globalization aspects create a specific context providing companies with new business opportunities, while simultaneously presenting them with new challenges they need to adapt to.In this regard,it is important for companies to recognize processes and understand trends brought by globalization in order to be able to make adequate business decisions and achieve success in the market. This particularly pertains to the companies from undeveloped and transition countries operating in an insufficiently developed and non-stimulating business environment.

Theoretical considerations of many authors analyzed the effects of globalization on companies. However, notwithstanding the numerous pieces of literature dealing with the issue of globalization and its effect on business performance of companies, there is an evident scarcity of empirical research on this subject, particularly in the Western Balkan countries. We recognized this gap and decided to carry out an empirical research on the effect of globalization on the companies from $\mathrm{B} \& \mathrm{H}$. In order to study the positive effects of globalization on B\&H companies, we performed the correlation-regression analysis of the relationship between independent variables defined as globalization opportunities (6 variables)and dependent variables-companies' performances (profit, sales, return on investment and company growth). Negative effects of globalization on B\&H companies were studied through correlation-regression analysis of the relationship between independent variables defined as globalization threats (5 variables) and dependent variables - companies' performances (profit, sales, return on investment and company growth). The research has shown that there are significant correlations between all independent and dependent variables, i.e. we concluded that globalization has both positive and negative effects on the companies in $\mathrm{B} \& \mathrm{H}$.

The paper consists of sections as follows. Section 1 provides an introduction; Section 2 provides theoretical basis and hypotheses, as well as overview of researches closely related to this paper's research subject; Section 3 describes methodology; Section 4 provides the empirical results of the research and, finally, Section 5 contains the conclusion.

\section{THEORETICAL BASES AND HYPOTHESES}

Many authors have noticed multiple and complex effects of globalization on the countries and companies all over the world (e.g. Acocella, 2005; Duuning, 2003; Dicken, 2004; Fridman, 2000; Gatignon and Kimberly, 2004; Gidens, 1990; Hadžiahmetović, 2011; Held, 1999; Hodžić, 2003; Mikusova, 2010; Porter, 2008; Stiglitz, 2004; Wignaraja, 2004; Karadagli, 2012). Globalization creates a specific context with direct implications on companies having positive and negative effects. According to Porter (2008), positive aspects of globalization pertain to the possibilities of acquiring inputs such as raw materials, capital and knowledgefrom anywhere, then spreading different activities abroad and utilization of cheaper workforce and capital, which helps achieving competitive advantage. Apart from this, globalization enables easier access to new technologies, new skills, new markets, new financial sources and, even more than ever before, better outside-oriented chances for future growth (Wignaraja, 2004). Successful enterprises perceive these enormous globalization opportunities and reap bountifully from the trends and practices that globalization provides (Obioma \& Clement, 2014). These possibilities are the reason that more and more firms (not only big corporations, but also small and medium-sizedcompanies) are striving to have an international presence, even though they face pressing challenges (Zain \& Ng, 2006).

Although it provides new opportunities for companies, globalization also causes new risks for them due to intense competition among companies worldwide (Hafsi, 2002; Harvey \& Novičević, 2002). Companies from developing countries are particularly exposed to risks, because commodities they produce must meet the global market criteria, primarily in terms of the price, quality and delivery standard. These global trends bring about new challenges the companies need to adapt to in order to remain competitive (Wignaraja, 2004). Apart from this, companies are also exposed to other negative effects of globalization, the strongest among them being the effects of the global economic crisis. Thus, instability in one region very quickly reflects itself on the jobs, production, savings and investments thousands of kilometers away (McGrew, 2010). 
Certain authors carried out empirical research on the impact of globalization on companies (e.g. Thoumrungroje \& Tansuhaj, 2007; Zain, Kassim \& Al-Mohannadi, 2009; Obioma \& Clement, 2014; Wignaraja 2004). Based on empirical and theoretical studies related to this subject, we have noticed the effect of two key globalization aspects on companies: globalization opportunities and globalization threats.

The aforementioned globalization aspects undoubtedly affect both the economy and companies in Bosnia and Herzegovina $(\mathrm{B} \& \mathrm{H})$ and many local authors have noted these trends (e.g. Hodžić, 2003; Stojanov, 2001; Hadžiahmetović, 2011; Domazet, 2006; Kurtović, 2003a; Kurtović, 2003b; Kurtović, 2008; Mahmutović \& Kulović, 2010; Mahmutović et al., 2014). Globalization and regionalization of market create strong competitive pressures on the market of $\mathrm{B} \& \mathrm{H}$ and simultaneously open numerous opportunities for the growth of the local companies through internationalization of business (Sendić, 2009). If the companies of $\mathrm{B} \& \mathrm{H}$ wish to be competitive and play a significant role in the international market and EU market in particular, they urgently need to adapt to global challenges and accept current principles and ways of doing business that are in place in the European and global companies (Mahmutović, 2010).

Notwithstanding the evident research problem, it can be concluded that the empirical research in this field in $\mathrm{B} \& \mathrm{H}$, as well as in other transition countries, is rather scarce. This particular fundamental observation initiated this paper's research on the impact of globalization on the companies in B\&H and their business performance. For the purpose of the research, the following hypotheses have been $\operatorname{set}^{2}$ : 1) Globalization opportunities positively impact the performance of the companies in $\mathrm{B} \& \mathrm{H}$ and 2) Globalization threats negatively impactthe performance of the companies in $\mathrm{B} \& \mathrm{H}$.

\section{RESEARCH METHODOLOGY}

Our research's main setpertaining to the observed phenomenon consists of 9,993 companies ${ }^{3}$. Empirical research has been carried out on a three-level stratified sample of $\mathrm{N}=133$ companieswith a confidence level of $95 \%$ and a margin of error of $5 \%$.Sample stratification has been performed in accordance with the classification of companies into small companies with 10 to 50 employees, medium-sized companies with 50 to 250 employees and large companies with over 250 employees ${ }^{4}$. As a research instrument we useda survey questionnaire, which was distributed by e-mail to the companies chosen by means of random sampling. The questionnaire was filled out by the company owners or high-ranking executives from the top management. Measurement instrument for hypothesis testing has been taken over from Thoumrungrojeand Tansuhaj (2007) (partially modified) and, in accordance with it, factors representing globalization opportunities and threats have been shown in the following tables 1 and 2 . The measurement has been carried out using a 5-point Likert response scale ranging from 1 to 5 .

GO1 Globalization has increased my firm's opportunities to develop customer markets worldwide.

GO2 Globalization has increased my firm's opportunities for trade and investment.

GO3 Globalization has increased my firm's market potential.

GO4 Globalization has increased my firm's opportunities to expand the firm's products and/or markets.

GO5 Globalization has facilitated my firm's international market expansion.

GO6 Globalization has made it easy for my firm to identify potential customers. 
Table 1. Measurement instrument-globalization opportunities

GO1 Globalization has increased my firm's opportunities to develop customer markets

GO2 Globalization has increased my firm's opportunities for trade and investment.

GO3 Globalization has increased my firm's market potential.

GO4 Globalization has increased my firm's opportunities to expand the firm's products and/or markets.

GO5 Globalization has facilitated my firm's international market expansion.

GO6 Globalization has made it easy for my firm to identify potential customers.

Table 2. Measurement instrument-globalization threat

GT1 Globalization has increased the difficulty in forecasting demand for the firm's products.

GT2 Markets have become increasingly uncertain due to globalization.

GT3 Globalization has caused unpredictable changes in consumer purchasing patterns.

GT4 Globalization has increased the number of competitors my company is facing.

GT5 Globalization has increased the level of competition my company is facing.

Based on the responses provided i.e. on the level of formance aspects are given in Table 3: managers' satisfaction, the measured company per-

Table 3. Company performance aspects

PF1-sales,PF2 -profit, PF3 -return on investment, PF4 -company growth 


\section{RESEARCH FINDINGS}

For the purpose of testing the set hypotheses by means of correlation analysis, we compared the surveyees' responses regarding globalization opportunities and threats with the company performance and the results are shown in Figure 1.

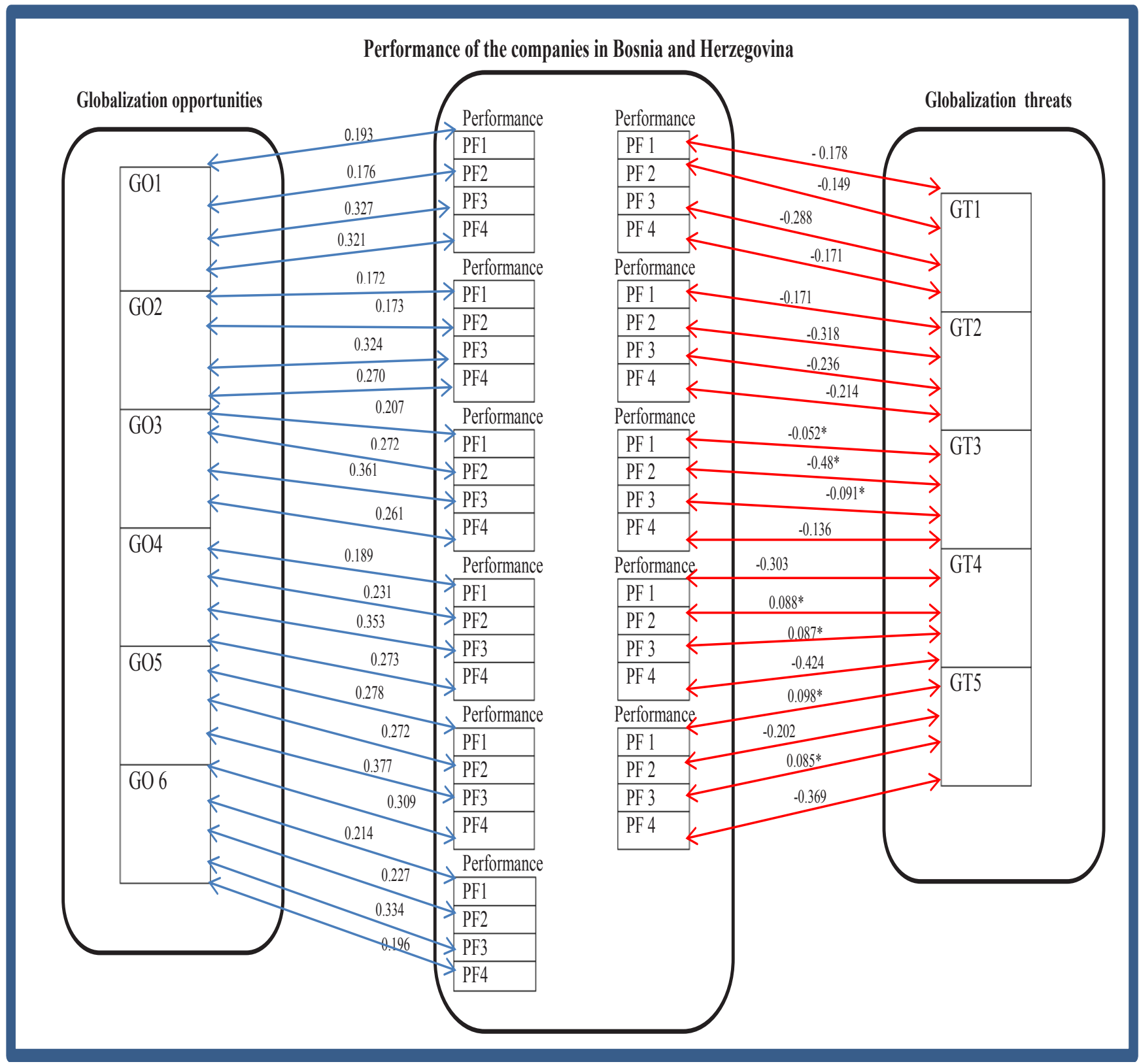

Figure 1. The impact of globalization on the companies'performance

Source: Author's own construct

* not significant $(\mathrm{p}>0.05)$

This paper uses Cohen's interpretation of correlations (Pallant, 2007, page 135), according to which "the correlation is divided into: small $\mathrm{r}=0.10$ to 0.29 , medium $r=0.30$ to 0.49 and large $r=0.50$ to 1.0 ". On the basis of the correlation analysis findings we can conclude that there are significant correlations $(p<0.05)$ of small and medium intensity between all the factors defined as globalization opportunities and the company performance, indicating that globalization opportunities have positive effect on the performance of the companies in Bosnia and Herzegovina. The concerned conclusion supports the first hypothesis stating that globalization opportunities positively impact the performance of the companies in Bosnia and Herzegovina. The reliability of the measurement scale i.e. the internal consistency of the factors defined as globalization opportunities has been checked by means of Cronbach alpha coefficient, which represents a measure of how closely related are a set of items as a group. According to majority of authors, this coefficient's minimum value should not be lower than 0.6. 
Table 4. The reliability of the measurement scalefor globalization opportunity factors

\section{Cronbach alpha}

0.941

\section{Number of factors}

6
Based on the resulting Cronbach alfacoefficient of 0.941, we hereby conclude that this is a high value proving the internal consistency of the measuring instrument i.e. that items measure the basic (latent) construct.

In regard to the negative effects of globalization, based on the correlation analysis findings, we can conclude that the following correlations between the globalization threat factors and the company performance are not significant ( $p>0.05$ ): Globalization has caused unforeseeable changes in the customers' behavior - Profit, Sales and Return on Investment, Globalization has increased the number of competitors - Sales, Return on Investment and Globalization has increased the level of competition- Sales, Return on Investment. Therefore, we cannot confirm that these globalization threat factors negatively affect the companies' performance. However, we can conclude that each factor defined as a globalization threat has significant correlation of small or medium intensity with at least one aspect of company performance. The conclusion in question supports the second hypothesis stating that globalization threats negatively impact the performance of the companies in $\mathrm{B} \& \mathrm{H}$.

The reliability of the measurement scale i.e. the internal consistency of the factors defined as globalization threats has also been checked by means of Cronbach alpha coefficient, which represents a measure of how closely related are a set of items as a group.

Table 5. The reliability of the measurement scale for globalization threat factors

\begin{tabular}{ll}
\hline \multicolumn{1}{c}{ Cronbach alpha } & \multicolumn{1}{c}{ Number of factors } \\
\hline 0.876 &
\end{tabular}

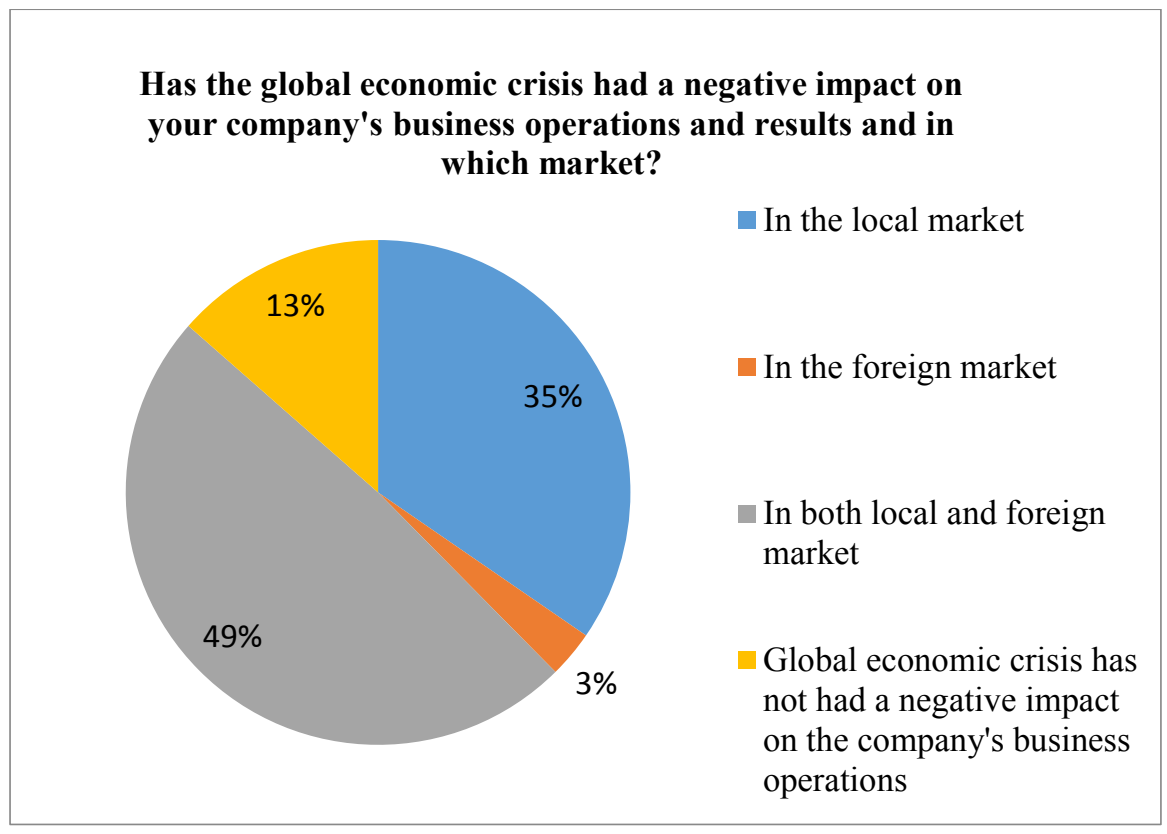

Figure 2. Negative impact of the global economic crisis on business operations and results of the companies in $B \& H$ in both local and foreign market.

Source: Author's own construct 
As is evident from Figure 2, the global economic crisis has affected almost all companies, its negative effects on business operations and results having been felt by as much as $87 \%$ of the companies. Thus, $35 \%$ of surveyees stated that the crisis had negatively affected only their operations in the local market, $3 \%$ of them stated that negative impact of the crisis had only been felt in the foreign market, while $49 \%$ of survey- ees reported registering negative effects of the crisis in both local and foreign market. Only $13 \%$ of the companies stated that the global economic crisis had not had a negative effect on their business operations and performance.Table 6 and Figure 3 below show the average effect of the global economic crisis on certain aspects of the performance of the companies in $\mathrm{B} \& \mathrm{H}$ expressed as percentages.

Table 6. The effect of the global economic crisis on the performance of the companies in B\&H, average expressed as percentages according to the size of the company.

\begin{tabular}{|c|c|c|c|c|c|}
\hline $\begin{array}{l}\text { Reduced scope of } \\
\text { production/service } \\
\text { s }\end{array}$ & $\begin{array}{l}\text { Reduced } \\
\text { profit }\end{array}$ & $\begin{array}{l}\text { Reduced } \\
\text { investment }\end{array}$ & $\begin{array}{l}\text { Reduced } \\
\text { number of } \\
\text { employees }\end{array}$ & $\begin{array}{l}\text { Slower } \\
\text { company } \\
\text { growth }\end{array}$ & $\begin{array}{l}\text { Weakened } \\
\text { company's } \\
\text { competitivenes } \\
\text { s }\end{array}$ \\
\hline $25.5 \%$ & $27.9 \%$ & $33.9 \%$ & $20.0 \%$ & $23.9 \%$ & $22.7 \%$ \\
\hline $23.9 \%$ & $28.9 \%$ & $35.6 \%$ & $18.4 \%$ & $22.5 \%$ & $19.4 \%$ \\
\hline $19.2 \%$ & $19.2 \%$ & $16.1 \%$ & $9.7 \%$ & $9.7 \%$ & $9.7 \%$ \\
\hline $24.9 \%$ & $27.9 \%$ & $33.7 \%$ & $19.2 \%$ & $23.0 \%$ & $21.4 \%$ \\
\hline
\end{tabular}
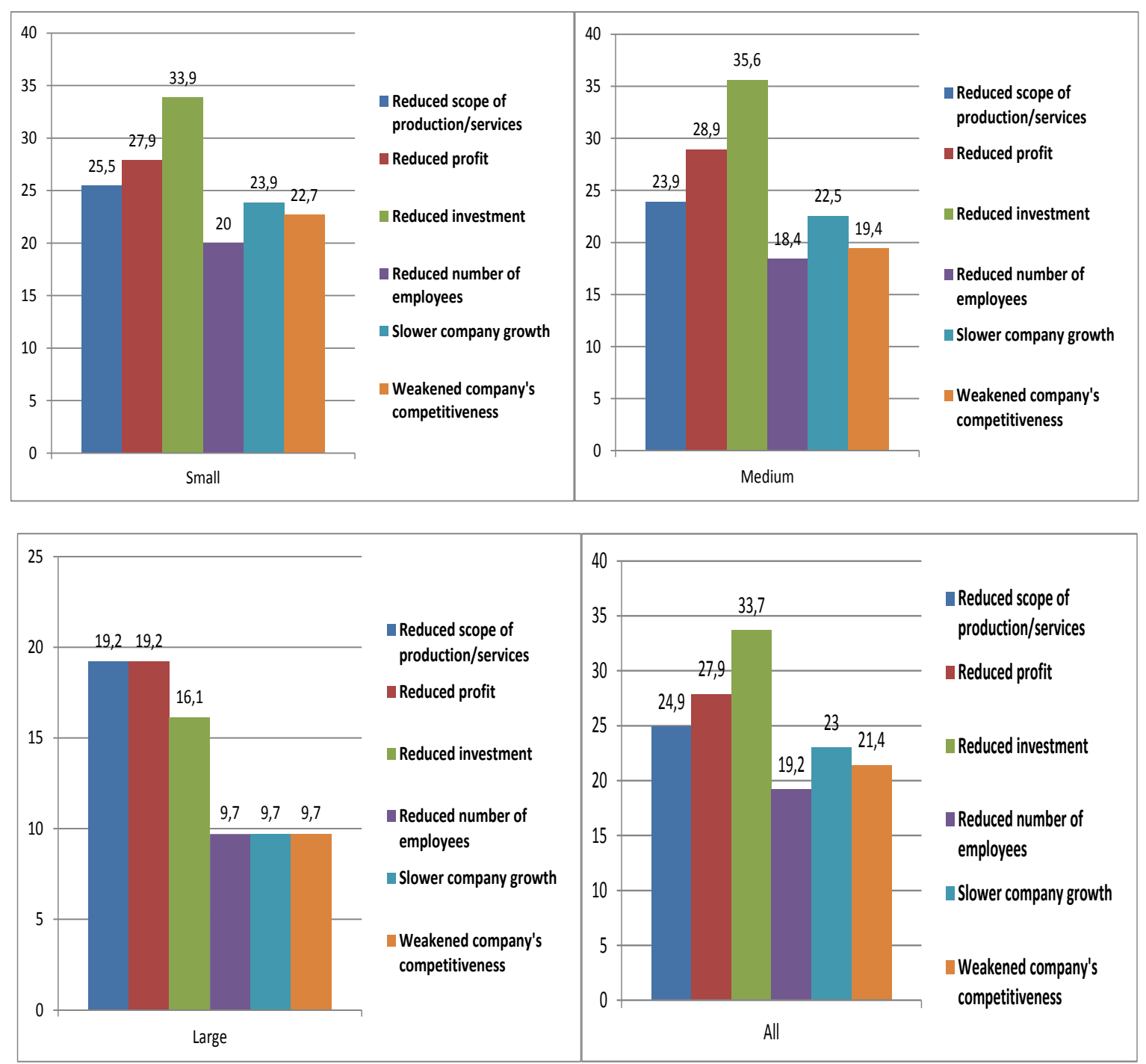

Figure 3. The effect of the global economic crisis on the performance of the companies, average expressed as percentages according to the size of the company. 
Based on the findings of the analysis of the impact of the global economic crisis on the companies in $\mathrm{B} \& \mathrm{H}$, we can conclude that there are significant effects on the companies' business performance. These effects range from the minimum $9.7 \%$ pertaining to the large companies' performance aspects such asreduced number of employees, slower company growth and reduced company's competitivenessto the maximum $35.6 \%$ pertaining to reduced investment for medium-sized companies. We can also conclude that the global economic crisis has equally affected the small and medium-sized companies, i.e. has had an equally negative impact on their business performance ranging from $18.4 \%$ (reduced number of employees) to $35.6 \%$ (reduced investment). The negative impact of the global economic crisis was felt less when it comes tobusiness performance of large companies and it ranges from the minimum 9.7\% (reduced number of employees, slower company growth and reduced company's competitiveness) to the maximum $19.2 \%$ (reduced scope of production, reduced profit). In comparison to the minimum and maximum impact on small and medium-sized companies, the impact of the crisis on large companies is $8.7 \%$ smaller than the minimum and $16.4 \%$ smaller than the maximum. The aforementioned data imply that the global economic crisis has had greater negative impact on small and medium-sized companies than on large companies. The above stated analysis supports the second hypothesis stating that globalization threats negatively impact the business performance of the companies in $\mathrm{B} \& \mathrm{H}$.

\section{CONCLUSION}

Based on the results of correlation analysis, we conclude that there are significant correlations at the 5\% level between all factors defined as global opportunities and the companies' performances, which implies that globalization opportunities positively affect the performance of $\mathrm{B} \& \mathrm{H}$ companies.In the case of globalization threats, we can conclude that every factor defined as a globalization threat has a significant correlation at the 5\% level with at least one company performance. Furthermore, we analyzed the negative effects of globalization through the impact of the global economic crisis on companies in B\&H.The analysis results show that the global economic crisis has had a significant impact on business performance of the companies. The consequences range from the minimum $9.7 \%$ for the following performances of large companies: reduced number of employees, slower company growth and reduced company's competitivenessto the maximum $35.6 \%$ for reduced investment for medium-sized companies. Also, we can conclude that the global economic crisis equally affected small and medium-sized companies i.e. had an equally negative impact on their business performance, ranging from $18.4 \%$ (reduced number of employees) to $35.6 \%$ (reduced investment). The negative effect of the global economic crisis was felt less in the case of large companies' performance and it ranges from the minimum $9.7 \%$ (reduced number of employees, slower company growth and reduced company's competitiveness) to the maximum $19.2 \%$ (reduced scope of production, reduced profit). In comparison with the minimum and maximum effect on small and medium-sized companies, the effect of the global crisis on large companies is $8.7 \%$ smaller than the minimum, and $16.4 \%$ smaller than the maximum. Based on the aforementioned data, we conclude that the negative effect of the global economic crisis was felt more strongly by small and mediumsized companies than by large companies.

This research's findings, taking companies in B\&H as an example, confirm the findings of the previous researches on double impact of globalization, showing, on the one side, its positive effects and, on the other side, its negative effects on the companies' performance. This provides significant support to the literature and theoretical knowledge of the authors dealing with the issue of globalization and its impact on companies. These conclusions are particularly important for the managers of the companies in $\mathrm{B} \& \mathrm{H}$, as well as in other transition countries, who should be prepared for doing business in the newly created global conditions. In regard to this, companies need to develop adequate strategies adapted to the global challenges in order to utilize globalization opportunities to achieve as great benefits as possible and avoid or minimize damage caused by globalization threats.

In addition, these conclusions are also relevant for all levels of government in B\&Hin the process of economic decision-making and drafting strategies. Economic policy measures should be aimed at creating a favorable business environment and enhancing competitiveness of the local companies. In this context, special economic policy measures should be created for the sector of small and medium-sized companies, which, according to the results of the research on the impact of the global economic crisis, have suffered more damage from globalization threats than large companies have. 
These conclusions can also be observed in the context of the findings of the research done by Mahmutović et al. (2014) on the positive effects of globalization on B\&H companies, stating that large companies use globalization opportunities in their business operations more than small and medium-sized companies do. The conclusion arising from this is that globalization has a more favorable impact on large B\&H companies than on small and medium-sized companies, because large companies gain more benefit from globalization opportunities, while suffering less damage from globalization threats.

This paper opens up the possibility for further research in this field to take place in other countries. It would be particularly interesting to compare the findings of researches on the impact of globalization on the companies from certain developed and developing countries. This would help us establish whether globalization equally impacts all companies, i.e. if it offers equal opportunities to everybody and if everyone suffers from the negative consequences of globalization to the same extent.

\section{REFERENCES}

Acocella, N. (2005). Economic policy in the Age of Globalization. New York: Cambridge University Press.

Dicken, P. (2004). Global Shift: Reshaping the Global Economic Map in the 21st Century. London: SAGE.

Domazet, A. (2006). Strategija promocije izvoza - konceptualni okvir za Bosnu i Hercegovinu. Sarajevo. Ekonomski institut Sarajevo (in Bosnian language only).

Dunning, J.H. (2003). Governments, Globalization and International Business. Oxford: Oxford University Press.

Džafić, Z i Bejić, J. (2012). Poduzetništvo i tržište rada: Mala i srednja preduzeća u funkciji povećanja zaposlenosti. Zagreb-Sarajevo: Synopsis (in Bosnian language only).

Easterly, W., Williamson, J., Banerjee, V. A. (2004). "Channels from Globalization to Inequality: Productivity World versus Factor World", in Collins, M.S, Graham, C., Brookings Trade Forum 2004: Globalization, Poverty and Inequality. Washington: The Brookings Institution, pp. 39-81.

Friedman, L.T. (2000). The Lexus and the Olive Tree: Understanding Globalization. New York: Anchor Books.

Gatignon, H., Kimberly R.J. (2004). The INSEAD - Wharton Alliance on Globalizing: Strategies for Building Successful Global Business. Cambridge: Cambridge University Press.

Gidens, E. (1991). The Consequences of Modernity. Cambridge: Polity Press.

Goldstein, N. (2007). Globalization and Free Trade. New York: Infobase Publising.

Hafsi, T (2002). "Global Competition and the Peripheral Player: A Promising Future", in Fawzy, S., ed., Globalization and Firm Competitiveness in the Middle East and North Africa Region. Washington DC: The International Bank of Reconstruction and Development, pp. 45-63.
Hadžiahmetović, A. (2011). Ekonomija Evropske unije. Sarajevo: Sarajevo University Press (in Bosnian language only).

Harvey, M, Novicevic, M.M. (2002). "The hypercompetitive global marketplace: the importance of intuition and creativity in expatriate managers". Journal of World Business, Vol. 37, No. 2, pp.127-138.

Held, D and McGrew, A. (1999). Global transformations. Stanford: Stanford University Press.

Hodžić, K., (2003). (Re)privatizacija i globalizacija. Sarajevo: Međunarodni Forum Bosna (in Bosnian language only).

Jepma, J.C., Rhoen, P.A. (1996). International trade: A business perspective. London: Longman.

Karadagli, E.C. (2012). "The Effects of Globalization on Firm Performance in Emerging Markets: Evidence from Emerging-7 Countries." Asian Economic and Financial Review, Vol. 2, No. 7, pp. 858-865.

Kurtović, S. (2003a). Misliti i poslovati u svetu globalnog biznisa. Beograd: Print grafik (in Bosnian language only).

Kurtović, S. (2003b), "Globalizacija izvor pozitivnih tenzija." Tranzicija, Vol. 5, No. 13 (in Bosnian language only).

Kurtović, H. (2008). "Globalisation Process in the World and their Impact on the Economic Policy of Bosnia and Herzegovina.” Paper presented at the conference „Identitet $\mathrm{i}$ globalizacija“. Zenica: Univerzitet u Zenici.

Mahmutović, H., Kulović, Dž. (2010). Upravljanje preduzećem. Beograd (in Bosnian language only).

Mahmutović, H., Hadžiahmetović, A, Talović, S. (2014). “Globalization Opportunities and Their Implications on Business Operations and Competitiveness of Companies in Bosnia and Herzegovina." Asian Economic and Financial Review, Vol. 4, No. 11, pp. 1638-1652.

McGrew, A (2010). "Globalization and Global Politics." in Baylis, J, Smith, S.And Owens, P., 5.th ed., Globalization of World Politics. Oxford: Oxford University Press, pp. 16-31.

Mikusova,M.(2010). “Challenges ofGlobalization.”Perspectives of Innovations, Economics \& Business, Vol. 6, No. 3, pp. 7-11.

Obioma, O.H., Clement A.A (2014). "Globalization: Effects on Small-Scale Business Development in Nigeria". International Journal of Economics, Commerce and Management, Vol 2, No 5.

O’Rourke, H.K. and Williamson, G.J (2000). "When Did Globalization Begin?"European Review of Economic History, Vol. 6, No.1., pp. 23-50.

Oman, C. (1999). "Technological Change, Globalisation of Production and the Role of Multinationals," in Hiemenz, U., ed., Growth and competition in the new global economy. Paris: OECD, pp. 37-58.

Pallant, J., (2007). SPSS Priručnik za preživljavanje. Beograd: Mirkoknjiga; English translation (M. Šućur, transl.) SPSS Survival Manual: A Step by Step Guide to Data Analysis Using SPSS for Windows (version 15), 3rd Ed . Sydney: Allen \&Unvin.

Porter, M. E. (2008). On competition. Boston: Harvard Business Press.

Sendić, R. (2009). Strategija nastupa preduzeća iz Bosne i Hercegovine na međunarodnom tržištu, $\mathrm{PhD}$ Theses. Univerzitet u Sarajevu: Ekonomski fakultet u Sarajevu (in Bosnian language only). 
Stiglitz, E.J., Globalizacija i dvojbe kojem izaziva. Zagreb: Algoritam; English translation (L.T. Potrebica, transl.), Globalization and its discontents, 1 st Ed. New York: Norton \& Company, Inc., 2002.

Stojanov, D., Medić, Đ. (2001), Makroekonomske teorije i politike u globalnoj ekonomiji - dominantne škole ekonomske misli. Sarajevo: Ekonomski fakultet u Sarajevu (in Bosnian language only).

Thoumrungroje, A., Tansuhaj, P. (2007), “Globalization Effect and Firm Performance".Jurnal of International Business Research, Vol. 6, No. 2, pp. .43-58.
Zain, M, Kassim, N. and Mohannadi, F. (2009), "Strategies of Qatari Family Businesses to Face Globalization”. Paper presented at the 26th Pan-Pacific Conference; Strategic Innovation through Collaboration and Convergence, Shenzhen, China, pp. 62-64.

Zain, M., Ng, S.I., (2006), "The impacts of network relationships on SMEs' internationalization process".Thunderbird International Business Review, Vol. 48, No. 2, pp. 183-205.

Wignaraja, G., (2004). "Building Business Competitiveness." Internationale Trade Forum Magazine, No. 2. 